\title{
Pemberdayaan Peternak dalam Usaha Penggemukan Sapi Potong di Desa Kenteng, Kecamatan Nogosari, Kabupaten Boyolali
}

\author{
Shanti Emawati ${ }^{1,3 *}$, Sudiyono ${ }^{1,3}$, Sutrisno Hadi Purnomo ${ }^{1,3}$, Suwarto ${ }^{2}$, Ayu Intan Sari ${ }^{1,3}$ dan Endang Tri \\ Rahayu ${ }^{1,3}$ \\ ${ }^{1}$ Program Studi Peternakan, Fakultas Pertanian, Universitas Sebelas Maret, Surakarta, Indonesia; ${ }^{2}$ Program Studi \\ Penyuluhan dan Komunikasi Pertanian, Fakultas Pertanian, Universitas Sebelas Maret, Surakarta, Indonesia; \\ ${ }^{3}$ Pusat Penelitian dan Pengembangan Pangan Gizi dan Kesehatan Masyarakat, LPPM Universitas Sebelas Maret, \\ Surakarta, Indonesia
}

Diterima: 7 Oktober 2020; Disetujui: 25 Oktober 2020

\begin{abstract}
Abstrak
Pasokan daging sapi dalam negeri salah satunya dipenuhi dari peternak yang berasal dari Desa Kenteng, Kecamatan Nogosari, Kabupaten Boyolali. Peternak di Desa Kenteng mengembangkan usaha sapi potong dengan membentuk Kelompok Tani Ternak (KTT) Sumber Makmur, KTT Taruban Mulyo dan KTT Ngudi Mulyo. Permasalahan yang dihadapi peternak di Desa Kenteng adalah kurang optimalnya usaha penggemukan sapi potong yang dijalankan oleh peternak. Tujuan dari kegiatan ini adalah memberdayakan peternak sapi potong yang tergabung dalam KTT di Desa Kenteng. Metode pengambilan lokasi dan responden dalam kegiatan ini adalah purposive sampling. Metode pelaksanaan kegiatan ini antara lain Focus Group Discussion (FGD), kegiatan penyuluhan dan pelatihan melalui penyusunan formulasi ransum pakan dan jerami padi fermentasi dalam usaha penggemukan sapi potong. Hasil dari kegiatan ini adalah pemberdayaan peternak dalam usaha penggemukan sapi potong melalui pelaksanaan kegiatan penyuluhan dan pelatihan penyusunan formulasi ransum dan pembuatan jerami fermentasi di Desa Kenteng berjalan dengan baik terlihat peternak menjadi lebih berdaya karena pengetahuan peternak meningkat dan pakan yang diujicobakan pada ternak dapat dikonsumsi dengan baik sehingga performa ternak meningkat. Kesimpulan dari kegiatan ini adalah peternak menjadi lebih berdaya dikarenakan pengetahuan peternak meningkat dan pakan yang diujicobakan pada ternak dapat dikonsumsi dengan baik sehingga meningkatkan performa ternak.
\end{abstract}

Kata kunci: pakan; pemberdayaan; penggemukan; peternak; sapi potong

\section{Empowerment of Farmers in Beef Cattle Feedlot in Village of Kenteng, Nogosari Sub- District, Boyolali Regency}

\begin{abstract}
Domestic beef supply is fulfilled by farmers from Kenteng Village, Nogosari Sub-district, Boyolali Regency. Farmers in Kenteng Village develop beef cattle business by forming a beef cattle farmers' groups Sumber Makmur, Taruban Mulyo and Ngudi Mulyo. The problem faced by farmers in Kenteng Village is that the business of beef cattle fattening is not optimal. The purpose of this activity is to empower beef cattle farmers who are members of the livestock farmer groups in Kenteng Village. The method of taking location and respondent in this activity is purposive sampling. This activity methods
\end{abstract}

\footnotetext{
*Corresponding author: shantiemawati@ staff.uns.ac.id

Cite this as: Emawati, S., Sudiyono, Purnomo, S. H., Suwarto, Sari, A. I., \& Rahayu, E. T. (2020). Pemberdayaan Peternak dalam Usaha Penggemukan Sapi Potong di Desa Kenteng, Kecamatan Nogosari, Kabupaten Boyolali. AgriHealth: Journal of Agri-food, Nutrition and Public Health, 1(2), 96-102. doi: http://dx.doi.org/10.20961/ agrihealth.v1i2.44736
} 
include Focus Group Discussion (FGD), extension and training activities through the preparation of feed rations and fermented rice straw. The result of this activity is the empowerment of farmers in the business of beef cattle fattening through the implementation of counseling and training for the preparation of ration formulations and fermented straw making in Kenteng Village, which is seen as being more empowered because the farmers' knowledge increases and the feed tested on livestock can be consumed properly so that livestock performance increases. The conclusion of this activity is that farmers become more empowered due to increased farmer knowledge and the feed tested on livestock can be consumed properly, thereby increasing livestock performance.

Keywords: breeder; beef cattle; empowerment; feed; feedlot

\section{PENDAHULUAN}

Kecamatan Nogosari merupakan salah satu kecamatan yang terletak di Kabupaten Boyolali. Kecamatan Nogosari secara geografis termasuk dalam wilayah Kabupaten Boyolali berada diantara $7^{\circ} 30^{\prime \prime}-7^{\circ} 45^{\prime \prime}$ LS dan $110^{\circ} 30^{\prime \prime}$ $110^{\circ} 45^{\prime \prime}$ BT. Kecamatan Nogosari secara umum merupakan daerah yang mempunyai ketersediaan air cukup melimpah dan struktur tanah yang subur dengan topografi antara 100-400 m dpl (meter di atas permukaan laut) maka daerah ini cocok untuk lahan pertanian.

Kecamatan Nogosari terdiri dari 13 desa dengan luas wilayah 5.508,43 ha. Salah satu desa di Kecamatan Nogosari adalah Desa Kenteng. Batas wilayah Desa Kenteng adalah sebelah utara berbatasan dengan Desa Tegalgiri, sebelah selatan dan timur berbatasan dengan Desa Sobokerto dan sebelah barat berbatasan dengan Desa Potronayan. Desa Kenteng memiliki luas persawahan sebesar 110,332 ha dan luas pekarangan 99,577 ha. Jumlah penduduk Desa Kenteng pada tahun 2017 tercatat penduduk laki-laki sebesar 2.789 jiwa dan penduduk perempuan 2.790 jiwa. Jumlah rumah tangga sebesar 450 keluarga (Data Monografi Desa Kenteng, 2017).

Desa Kenteng merupakan salah satu wilayah di Kecamatan Nogosari yang memiliki potensi usaha penggemukan sapi potong dengan populasi ternak sapi potong sebesar 260 ekor dari 230 peternak. Kendala/permasalahan yang dihadapi peternak sapi potong di Desa Kenteng antara lain (1) peningkatan produktivitas ternak kurang sebanding dengan biaya pakan yang dikeluarkan. Pemanfaatan limbah pertanian berbasis potensi sumber daya lokal belum dimanfaatkan secara optimal sehingga biaya pakan yang dikeluarkan cukup tinggi. Selain itu, kurangnya pengetahuan peternak dalam menyusun formulasi pakan yang berkualitas sehingga pakan yang diberikan kurang memenuhi kebutuhan nutrien yang disyaratkan pada ternak untuk meningkatkan pertambahan berat badan ternak, (2) ketersediaan pakan hijauan bagi ternak pada musim penghujan melimpah. Namun pada musim kemarau peternak kekurangan pakan hijauan. Peternak hanya memberikan jerami padi untuk pakan ternak. Padahal kandungan nutrien yang terdapat dalam jerami padi rendah. Oleh karena itu perlu dilakukan proses teknologi pengolahan pakan untuk meningkatkan kualitas jerami padi tersebut.

Menurut Syamsu dan Karim (2013) bahwa jerami padi adalah salah satu limbah pertanian yang sering dipakai untuk pakan ternak, namun beberapa peternak belum memanfaatkannya secara optimal. Jerami padi berpotensi sebagai sumber pakan ternak karena jumlahnya yang melimpah dan mudah diperoleh (Robiyanto et al., 2018). Menurut Hidayat dan Purnama (2005), permasalahan pada pemanfaatan jerami padi adalah rendahnya nilai gizi dan koefisien cerna padi yang merupakan pembatas selain palatabilitas yang rendah.

Berdasarkan keinginan peternak untuk mengembangkan usahanya, maka dilakukan upaya pemberdayaan peternak sapi potong melalui pelatihan usaha penggemukan sapi potong di Desa Kenteng, Kecamatan Nogosari, Kabupaten Boyolali. Menurut Sidu (2006), tujuan pemberdayaan adalah membentuk individu dan masyarakat menjadi mandiri. Kemandirian tersebut meliputi kemandirian berpikir, bertindak dan mengendalikan apa yang dilakukan. Kemandirian masyarakat adalah merupakan suatu kondisi yang dialami oleh masyarakat dan ditandai kemampuan memikirkan, memutuskan serta melakukan sesuatu yang dipandang tepat demi mencapai pemecahan 
masalah yang dihadapi dengan mempergunakan daya, kekuatan atau kemampuan yang dimiliki. Daya, kekuatan atau kemampuan yang dimaksud adalah kemampuan kognitif, konatif, psikomotorik dan afektif serta sumber daya lainnya yang bersifat fisik-material. Keberhasilan proses pemberdayaan sangat tergantung dari dukungan faktor-faktor physical capital, human capital, social capital dan kemampuan pelaku pemberdayaan. Berdasarkan latar belakang tersebut perlu dilakukan pemberdayaan peternak anggota Kelompok Tani Ternak (KTT) melalui kegiatan penyuluhan dan pelatihan penyusunan formulasi ransum pakan dan jerami padi fermentasi dalam usaha penggemukan sapi potong di Desa Kenteng, Kecamatan Nogosari, Kabupaten Boyolali.

\section{BAHAN DAN METODE}

Kegiatan ini dilaksanakan di Desa Kenteng, Kecamatan Nogosari, Kabupaten Boyolali. Waktu pelaksanaan kegiatan ini adalah tanggal 28 Mei sampai dengan 27 Juli 2018. Metode pengambilan lokasi dan responden adalah metode purposive sampling dengan pertimbangan bahwa di lokasi tersebut memiliki prospek pengembangan usaha penggemukan sapi dengan jumlah populasi ternak sapi yang cukup tinggi dan peternak bergabung dalam KTT Sumber Makmur, KTT Taruban Mulyo, dan KTT Ngudi Mulyo. Pemilihan secara purposive berarti sampel dipilih dan ditetapkan berdasarkan pertimbangan-pertimbangan tertentu yang sesuai dengan tujuan penelitian (Sugiyono, 2006).

Data dianalisis dengan analisis deskriptif. Analisis deskriptif adalah analisis yang digunakan untuk menganalisa data dengan cara mendeskripsikan atau menggambarkan data yang telah terkumpul sebagaimana adanya tanpa bermaksud membuat kesimpulan yang berlaku untuk umum atau generalisasi (Sugiyono, 2012).

Metode pelaksanaan yang digunakan dalam kegiatan ini adalah :

1. Peningkatan pengetahuan mengenai tata laksana pemeliharaan usaha penggemukan sapi potong

Upaya peningkatan pengetahuan ini melalui kegiatan penyuluhan dan Focus Group Discussion (FGD) dengan melibatkan instansi terkait, peternak serta tokoh masyarakat untuk menggali data agar diperoleh pemecahan masalah yang selama ini dihadapi peternak dalam hal tata laksana pemeliharaan usaha penggemukan sapi potong dan manajemen pakan. Peningkatan pengetahuan usaha penggemukan sapi potong melalui peningkatan a.) aspek produksi yaitu peningkatan pengetahuan peternak melalui kegiatan FGD untuk meningkatkan tata kelola usaha penggemukan sapi potong; b.) aspek pakan yaitu penerapan penyusunan formulasi ransum dan penerapan pembuatan jerami fermentasi; c.) pengadaan alat pendukung yaitu pengadaan chooper untuk menunjang pembuatan jerami padi fermentasi.

\section{Penerapan penyusunan formulasi ransum ternak sapi}

Penerapan penyusunan formulasi ransum ini melalui penyuluhan dan pelatihan penyusunan formulasi ransum dengan suplemen Growth Promoting Feed Supplement (GPFS) yang berbahan dasar pakan jerami padi fermentasi (50\%), konsentrat (30\%) dan suplemen GPFS $(20 \%)$. Formula GPFS yang terdiri dari urea (1\%), molasses (5\%), bungkil sawit (10\%), minyak (2\%), mineral dan vitamin $(2 \%)$.

\section{Penerapan teknologi jerami padi fermentasi}

Bahan, peralatan dan cara yang digunakan dalam pembuatan jerami padi fermentasi cukup sederhana. Bahan baku yang digunakan adalah jerami padi 1 ton, $6 \mathrm{~kg}$ starbio dan $6 \mathrm{~kg}$ urea, sedangkan peralatan yang digunakan adalah naungan, selang, plastik, bambu, garpu jerami dan tali rafia. Cara pengolahan jerami padi fermentasi adalah sebagai berikut :

a. Jerami padi ditumpuk $30 \mathrm{~cm}$;

b. Menaburkan urea dan starbio,

c. Menambahkan air (dipercik) hingga kadar $60 \%$;

d. Mengulangi perlakuan tersebut hingga ketinggian minimal $1 \mathrm{~m}$;

e. Setelah 21 hari dibongkar untuk dikeringkan sebagai stok pakan atau langsung diberikan ke ternak (Lembah Hijau Multifarm, 1999). 


\section{Pengadaan/pembuatan mesin pencacah rumput/chooper}

Pengadaan mesin Chooper digunakan untuk mencacah rumput sebelum dilakukan proses pembuatan jerami padi fermentasi.

\section{HASIL DAN PEMBAHASAN}

Kegiatan survei dan pendekatan masyarakat

Tim kegiatan telah melakukan kegiatan survei dan pendekatan masyarakat di ketiga mitra yaitu KTT Taruban Mulyo, KTT Sumber Makmur dan KTT Ngudi Mulyo di Desa Kenteng, Kecamatan Nogosari, Kabupaten Boyolali untuk mengetahui informasi lengkap tentang permasalahan yang dihadapi kelompok mitra dan beberapa solusi pemecahan masalah melalui program-program yang dilakukan. Penentuan prioritas permasalahan serta pemecahan masalah dilakukan dengan kegiatan FGD. FGD diikuti oleh perwakilan instansi pemerintahan, perangkat desa, pengurus dan anggota KTT. Pada awal program, tim kegiatan melakukan kegiatan pendekatan masyarakat serta koordinasi dengan ketiga mitra yaitu KTT Taruban Mulyo, KTT Sumber Makmur dan KTT Ngudi Mulyo berkaitan dengan kegiatan penyuluhan dan pelatihan yang dilaksanakan di Desa Kenteng, Kecamatan Nogosari, Kabupaten Boyolali.

Berdasarkan hasil survei, pendekatan masyarakat dan pelaksanaan FGD bahwa permasalahan yang dihadapi peternak antara lain dari aspek produksi yang terkait dengan tata kelola usaha penggemukan sapi potong dan aspek pakan yang kurang optimal. Solusi pemecahan masalah adalah melakukan kegiatan penyuluhan dan pelatihan tentang tata laksana pemeliharaan usaha penggemukan sapi potong dan penyusunan formulasi pakan serta pembuatan jerami padi fermentasi.

\section{Kegiatan penyuluhan}

Pelaksanaan kegiatan penyuluhan dihadiri oleh peternak-peternak anggota KTT yang tergabung dalam KTT Taruban Mulyo, KTT Sumber Makmur dan KTT Ngudi Mulyo. Jumlah peternak yang hadir mengikuti kegiatan penyuluhan dan pelatihan sebesar 31 orang. Materi yang disampaikan dalam kegiatan penyuluhan antara lain Business Plan pada usaha kecil, manajemen penggemukan sapi potong, teknologi pengolahan pakan konsentrat dan teknologi fermentasi jerami. Kegiatan penyuluhan berjalan dengan lancar terlihat dari banyaknya peternak yang hadir dan antusiasnya peternak mengikuti penyuluhan. Peternak aktif dalam sesi diskusi dan tanya jawab pada saat pelaksanaan kegiatan penyuluhan. Hal ini menunjukkan minat yang besar dari peternak untuk memperbaiki pengelolaan usahanya dan meningkatkan produktivitas ternak agar ke depannya memberikan hasil yang optimal. Kegiatan penyuluhan disajikan pada Gambar 1, Gambar 2, Gambar 3 dan Gambar 4.

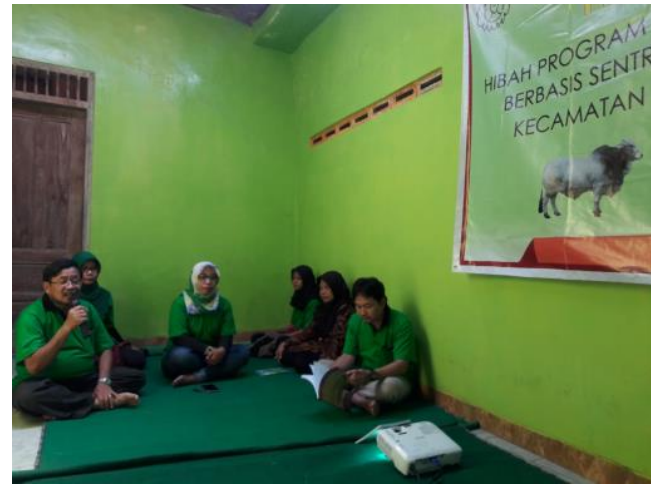

Gambar 1. Sambutan tim pelaksana dalam kegiatan penyuluhan dan pelatihan

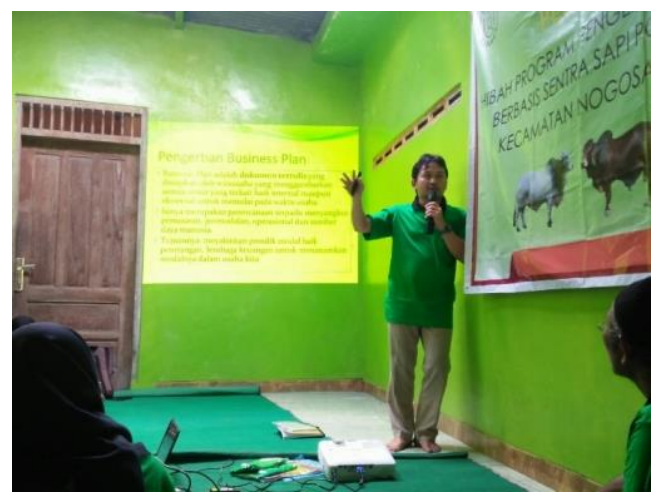

Gambar 2. Tim pelaksana menyampaikan materi pelatihan

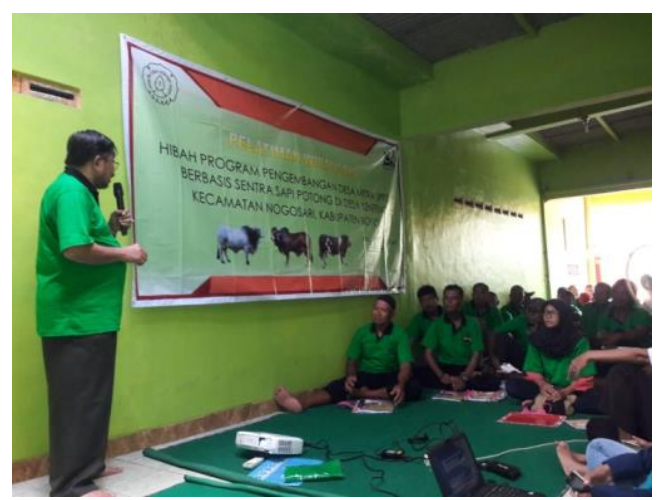

Gambar 3. Narasumber menyampaikan materi tentang manajemen pakan 


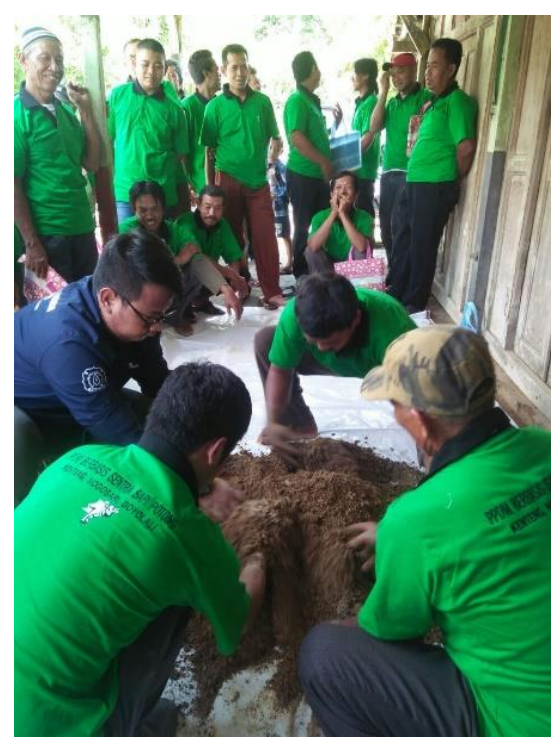

Gambar 4. Pelatihan dan praktek penyusunan formulasi ransum

\section{Pelaksanaan pelatihan penyusunan formulasi ransum dan jerami padi fermentasi}

Tim pelaksana berkoordinasi dengan peternak anggota KTT yaitu KTT Taruban Mulyo, KTT Sumber Makmur dan KTT Ngudi Mulyo berkaitan dengan pelatihan penyusunan formulasi ransum sapi potong. Aplikasi ransum pakan untuk meningkatkan berat badan harian sapi ini menggunakan suplemen GPFS dengan berbahan dasar pakan jerami padi fermentasi (50\%), konsentrat (30\%) dan suplemen GPFS (20\%). Formula GPFS yang terdiri dari meliputi urea, molasses, bungkil sawit, minyak, mineral dan vitamin. Kurang optimalnya produktivitas ternak sapi menjadi latar belakang tim pelaksana memberikan pelatihan penyusunan formulasi ransum dengan suplemen GPFS agar produktivitas ternak meningkat. Berdasarkan penelitian Widyawati et al. (2013), pemberian pakan dengan suplemen GPFS mampu meningkatkan pertambahan berat badan sapi hingga kisaran 0,5-0,85 kg ekor ${ }^{-1}$ hari $^{-1}$.

Pembuatan jerami fermentasi dilatarbelakangi sebagian peternak belum melakukan pengolahan jerami padi. Pelatihan pembuatan jerami padi fermentasi memberikan manfaat kepada peternak karena dapat meningkatkan kualitas jerami padi sebagai pakan ternak sehingga dapat membantu mengurangi pembelian pakan hijauan serta dapat memperbaiki produktivitas ternak di Desa Kenteng. Menurut Yanuartono et al. (2017), bahwa kelemahan dari jerami padi sebagai pakan ternak adalah daya cerna dan nilai gizi yang rendah. Oleh karena itu, perlu pengolahan jerami padi, hal ini dimaksudkan untuk menurunkan kadar serat kasar yang tinggi dan meningkatkan kadar protein jerami padi, dengan proses amoniasi dan fermentasi menggunakan bantuan bakteri selulolitik (Wina, 2005). Upaya peningkatan nilai gizi, kecernaan sekaligus palatabilitasnya dapat dilakukan melalui proses fermentasi. Baset et al. (2013) menyatakan bahwa jerami yang difermentasi dengan urea, dapat meningkatkan berat badan ternak. Pelaksanaan pelatihan penyusunan formulasi ransum sapi dan jerami padi fermentasi serta pemberian pakan sapi dapat dilihat pada Gambar 4, Gambar 5 dan Gambar 6.

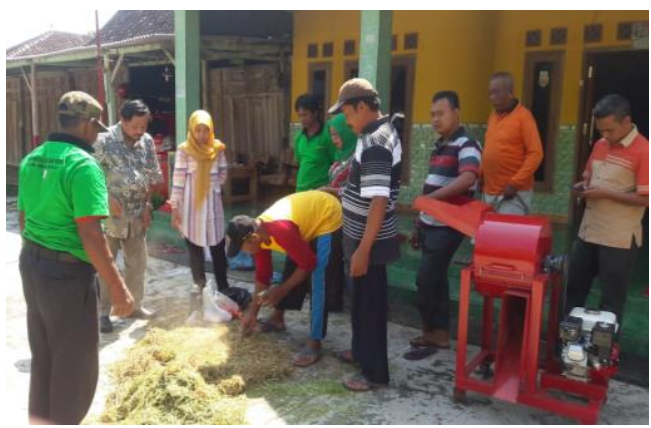

Gambar 5. Praktek pembuatan fermentasi jerami padi

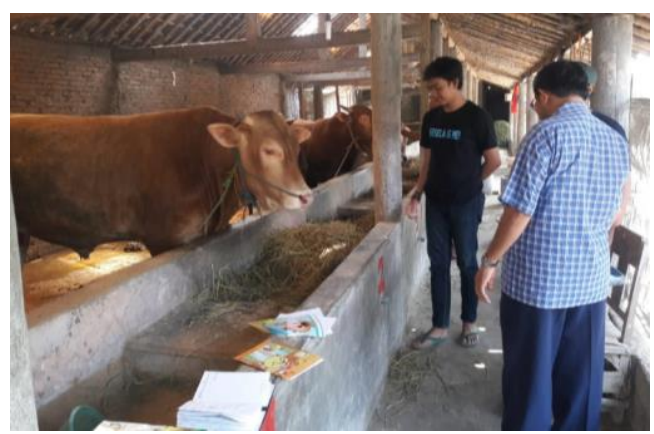

Gambar 6. Pemberian pakan pada ternak sapi milik peternak anggota KTT

Peternak aktif berperan serta dalam kegiatan pelatihan penyusunan formulasi ransum dan pembuatan jerami padi fermentasi sehingga pengetahuan dan ketrampilan peternak meningkat. Peternak menjadi lebih berdaya dengan adanya kegiatan penyuluhan dan pelatihan. Menurut Suharto (2005) bahwa pemberdayaan adalah sebuah proses dan tujuan. Tujuan pemberdayaan menunjuk pada keadaan atau hasil yang ingin dicapai oleh sebuah perubahan sosial, yaitu masyarakat menjadi berdaya, mempunyai pengetahuan 
dan kemampuan dalam memenuhi kebutuhan hidup, memiliki kepercayaan diri, mampu menyampaikan aspirasi, mempunyai mata pencaharian, berpartisipasi dalam kegiatan sosial dan mandiri dalam melaksanakan kehidupan.

Tim pelaksana melakukan kegiatan monitoring, pendampingan, pemberian pakan sebagai demplot pemeliharaan ternak sapi kepada peternak anggota KTT Taruban Mulyo, KTT Sumber Makmur dan KTT Ngudi Mulyo. Berdasarkan pengamatan menunjukkan bahwa ternak sapi dapat mengkonsumsi pakan dengan baik sehingga performa ternak menjadi lebih baik.

\section{Pengadaan alat pemotong rumput (chooper)}

Tim pelaksana menjelaskan prosedur penggunaan alat pemotong rumput/chooper serta dilanjutkan uji coba alat pemotong rumput/ chooper menggunakan sampel rumput/jerami dapat dilihat pada Gambar 7 dan Gambar 8.

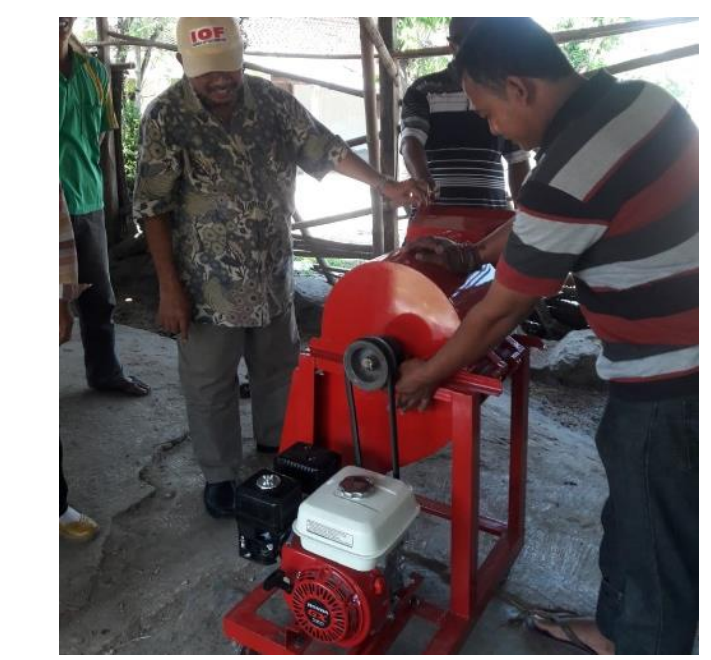

Gambar 7. Penjelasan penggunaan alat pencacah rumput/chooper

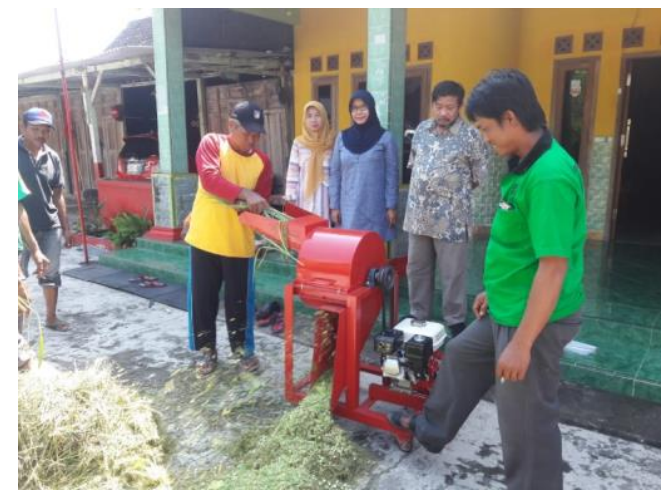

Gambar 8. Uji coba alat pencacahan rumput/ chooper

\section{KESIMPULAN}

Kesimpulan dari kegiatan ini adalah pemberdayaan peternak dalam usaha penggemukan sapi potong melalui pelaksanaan kegiatan penyuluhan dan pelatihan penyusunan formulasi ransum dan pembuatan jerami fermentasi di Desa Kenteng berjalan dengan baik terlihat peternak menjadi lebih berdaya karena pengetahuan peternak meningkat dan pakan yang diujicobakan pada ternak dapat dikonsumsi dengan baik sehingga performa ternak meningkat.

\section{UCAPAN TERIMA KASIH}

Penulis mengucapkan terima kasih kepada Kementerian Riset dan Teknologi/Badan Riset dan Inovasi Nasional (Kemenristek/BRIN) atas didanainya kegiatan ini yang bersumber dari skim Program Pengembangan Desa Mitra (PPDM), kepada perangkat desa dan masyarakat di Desa Kenteng, Kecamatan Nogosari, Kabupaten Boyolali.

\section{DAFTAR PUSTAKA}

Baset, M. A., Rachman, M. M., Islam, M.S., Ara, A., \& Kabir, A. S. M. (2013). Beef cattle production in Bangladesh - a review. Journal of Biological Sciences, 3(1), 8-25. https://dx. doi.org/10.3923/jbs.2003.8.25

Data Monografi Desa Kenteng. (2017). Daftar Isian Tingkat Perkembangan Desa dan Kelurahan tentang Pedoman Penyusunan dan Pendayagunaan Data Profil Desadan Kelurahan. Dinas Pemberdayaan Masyarakat dan Desa. Kabupaten Boyolali.

Hidayat \& Purnama, R. D. (2005). Pemanfaatan Jerami Padi Fermentasi (JPF) sebagai Pakan Penggemukan Sapi Potong di Kecamatan Banyu Resmi Kabupaten Garut. Prosiding Temu Teknis Nasional Tenaga Fungsional Pertanian. Balai Penelitian Ternak, Bogor, 26-30. Tersedia dari http://balitnak.litbang. pertanian.go.id/index.php/publikasi/category/ 69-3? download $=1155 \% 3 \mathrm{~A} 3$

Lembah Hijau Multifarm. (1999). Modul Pelatihan Integrated Farming System. CV Lembah Hijau Multifarm_Research Station, Solo. 
Robiyanto, Kusnadi, H., \& Yesmawati. (2018). Peningkatan Pengetahuan Peternak Sapi Potong terhadap Teknologi Pengolahan Jerami Padi di Kabupaten Seluma. In: Herlinda S et al. (Eds.), Prosiding Seminar Nasional Lahan Suboptimal 2018, Palembang 18-19 Oktober 2018. pp. 488-494. Palembang: Unsri Press. Tersedia dari http://conference.unsri.ac.id/ index.php/lahansuboptimal/article/view/1259

Sidu, D. (2006). Pemberdayaan Masyarakat Sekitar Hutan Lindung Jompi, Kabupaten Muna, Propinsi Sulawesi Tenggara. Disertasi. Pasca Sarjana Institut Pertanian Bogor. Bogor. Tersedia dari https://repository.ipb.ac.id/han dle/123456789/40649

Suharto, E. (2005). Membangun masyarakat memberdayakan rakyat: kajian strategis pembangunan kesejahteraan sosial dan pekerjaan sosial. Bandung: Rafika Aditama.

Sugiyono. (2006). Metode penelitian Bisnis. Cetakan 9. Bandung: CV. Alfabeta.

Sugiyono. (2012). Metode penelitian kuantitatif kualitatif dan $R \& D$. Bandung: CV. Alfabeta.

Syamsu, J., \& Karim, H. (2013). The Policy strategy of rice straw utilization of as feed for ruminants. Asian Journal of Agriculture and Rural Development, 3(9), 615-621. Tersedia dari https://ideas.repec.org/a/asi/ajosrd/2013p 615-621.html

Widyawati, S. D., Suprayogi, W. P. S., \& Utomo, R. (2013). Suplementasi pakan sumber energi dengan tingkat degradasi yang berbeda sebagai upaya perbaikan performan sapi pada peternakan rakyat. Laporan Akhir Penelitian Unggulan Perguruan Tinggi. Universitas Sebelas Maret. Surakarta.

Wina, E. (2005). Teknologi pemanfaatan mikroorganisme dalam pakan untuk meningkatkan produktivitas ternak ruminansia di Indonesia: Review. Wartazoa, 15(4), 173183. Tersedia dari http://medpub.litbang. pertanian.go.id/index.php/wartazoa/article/vie wFile/817/826

Yanuartono, H. Punamaningsih, S., Indarjulianto, \& Nururrozi, A. (2017). Potensi jerami sebagai pakan ternak ruminansia. Jurnal Ilmu-Ilmu Peternakan, 27(1), 40-61. http://dx.doi.org/ 10.21776/ub.jiip.2017.027.01.05 